\title{
PENGARUH TEMPERATUR ANNEALING TERHADAP SIFAT FISIS BATU BATA LIMBAH SERAT ALAMI
}

\author{
Artha Nesa Chandra ${ }^{1}$, Djusmaini Djamas ${ }^{2}$, Ramli $^{2}$ \\ ${ }^{1}$ Jurusan Pedidikan Fisika Fakultas Tarbiyah dan Ilmu Keguruan IAIN Batusangkar. \\ Jl. Sudirman No. 137 Kubu Rajo Lima Kaum Batusangkar. \\ Jurusan Fisika FMIPA Universitas Negeri Padang \\ Email: arthanesachandra@yahoo.co.id
}

\begin{abstract}
This study aims to determine at what temperature annealing which will produce compressive strength and good porosity in the brick waste natural fiber. This study was an experimental study with dick variables such as the proportion of clay and waste of natural powder that is $90 \%: 10 \%$, each grain size $0.18 \mathrm{~mm}$ material, waste natural powder used is sawdust sawmill. The independent variable is the temperature annealing while the dependent variable is the compressive strength and porosity. And wastes natural clay powder mixed and given 5 liters of water, then in print square shaped measuring $6 \times 6 \times 6 \mathrm{~cm}$ by 20 pieces to determine the compressive strength and the cylindershaped measuring $10 \times 7 \mathrm{~cm}$ by 4 units to determine the value of porosity. Each of these samples with variations in-Anneal Annealing temperature $7000 \mathrm{C}, 7500 \mathrm{C}, 8000 \mathrm{C}$ and $8500 \mathrm{C}$ using Electric Furnace. After data collection and data analysis of compressive strength and porosity of the importance of the value of the maximum compressive strength of $89.5 \mathrm{~kg} / \mathrm{cm} 2$ at a temperature of $8500 \mathrm{C}$ and this value meets the standards. While the minimum porosity value was $2.10 \%$ at the temperature of $8500 \mathrm{C}$.
\end{abstract}

Key words: bricks waste of natural fibers, annealing temperature, porosity, compressive strength

\section{PENDAHULUAN}

Pembangunan fisik di Indonesia sekarang ini, khususnya di Sumatera Barat, terus meningkat. Pembangunan gedung-gedung bertingkat, bangunan perumahan, perkantoran dan konstruksi lainnya itu tidak terlepas dari bahan bangunan. Bahan bangunan ini harus mempunyai kualitas baik, porositas yang kecil dan bersifat kuat serta kokoh. Faktor-faktor ini perlu diperhatikan mengingat daerah Indonesia terutama Sumatera Barat merupakan daerah yang rawan gempa.

Salah satu bahan bangunan yang berhubungan dengan kekuatan, kekokohan, porositas dan kualitas adalah batu bata. Batu bata biasanya dipakai untuk dinding bangunan. Batu bata dibuat dengan bahan dasar lempung yang diolah dan dibakar sampai suhu tertentu sehingga menjadi kuat, kokoh, bentuknya tetap dan pori-porinya tidak banyak. Standar yang digunakan untuk menentukan kualitas Batu bata adalah Standar Nasional Indonesia (SNI), yaitu SNI 15-2094-1991 (DSN, 1991).

Penelitian untuk mendapatkan kualitas batu bata yang sesuai dengan SNI sudah dilakukan seperti penelitian Ade Indra (2013) mengenai "Pengaruh Temperatur pembakaran pada komposit lempung/silika RHA terhadap sifat fisis (aplikasi pada bata merah)", serta penelitian mengenai "Perilaku Suhu dan Waktu Pembakaran terhadap Ciri Batu Bata Merah" 
(Anshar, dkk, 2001) hanya membahas dampak lama pemanasan (Annealing), suhu pemanasan (Annealing) dan cara pemanasan (Annealing) terhadap kuat tekan batu bata. Begitu juga dengan penelitian mengenai penambahan material campuran terhadap sifat-sifat batu bata. Penambahan material campuran pada pembuatan batu bata mempengaruhi kekuatan, porositas dan kualitas batu bata. Penambahan material campuran ini dapat berupa limbah serat alami. Seperti yang kita ketahui, limbah serat alami seperti sekam padi, serbuk kayu penggergajian dan ampas tebu, cukup banyak tersedia di Indonesia, khususnya daerah Sumatera Barat. Limbah-limbah tersebut berasal dari limbah pertanian dan limbah industri pengolahan kayu. Limbah-limbah tersebut belum banyak dimanfaatkan, biasanya hanya dibuang percuma atau dibakar sia-sia. Dan akhirnya akan menjadi masalah lingkungan.

Banyak upaya yang dilakukan guna pemanfaatan limbah serat alami itu menjadi barang yang bernilai ekonomis, misalnya penelitian terdahulu mengenai penelitian "Kualitas batu bata merah dengan penambahan serbuk gergaji" (Handayani. Sri, 2010), serta penelitian mengenai "Penambahan abu jerami dan abu sekam padi pada campuran batu bata untuk meningkatkan kualitas dan efisiensi produksi batu bata industri tradisional" (Ramawati. A, dkk, 2015), serta penelitian I Made Nada (2013) tentang " Karakteristik fisik campuran batu bata dengan memanfaatkan abu sisa pembakaran limbah kayu". Tetapi penelitian mengenai pengaruh temperatur pengeringan seperti Temperatur Annealing terhadap sifat fisis batu bata yang menggunakan lempung dan campuran limbah serat alami belum pernah diteliti.

Bertitik tolak dari latar belakang di atas, maka dalam rangka pengembangan bahan bangunan yang lebih berkualitas dan pemanfaatan limbah serat alami, penulis tertarik untuk melakukan penelitian mengenai Pengaruh Temperatur Annealing Terhadap Kuat Tekan dan Porositas batu Bata Limbah Serat Alami. Tujuan penelitian ini adalah untuk mengetahui Temperatur Annealing berapakah yang akan menghasilkan kuat tekan dan porositas yang baik pada Batu Bata Limbah Serat Alami.

Menurut SNI 15-2094-1991, batu bata adalah unsur bahan bangunan yang digunakan untuk pembuatan konstruksi bangunan, dibuat dari lempung dengan atau tanpa campuran bahan-bahan lain, dibakar pada suhu yang cukup tinggi hingga tidak dapat hancur lagi bila direndam dalam air. Batu Bata yang digunakan sebagai bahan bangunan selain memenuhi SNI dan juga harus berkualitas tinggi. Menurut Munandar (2001), tinggi rendahnya kualitas batu bata bergantung pada : kualitas lempung sebagai bahan mentah, bahan campuran, metode serta pengawasan proses pengolahan dan proses pembakaran. Batu Bata mempunyai sifat-sifat fisis seperti kuat tekan dan porositas. Berdasarkan bahan penyusunnya batu bata terdiri dari lempung dan limbah serat alami berupa serbuk kayu penggergajian.

Lempung adalah bahan berbutir halus $(<0,002 \mathrm{~mm})$, terdapat secara alami dan bersifat tanah, tersusun oleh mineral-mineral lempung (senyawa alumina silikat hidrat) dan mineral non lempung sebagai impuritinya. Lempung merupakan partikel yang sangat halus yang hanya dapat dilihat menggunakan mikroskop elektron. (Sutopo,1997). Untuk pemanfaatan lempung sebagai komponen dasar batu bata, harus diketahui sifat- sifat fisis lempung yaitu keplastisan, penyusutan, warna, dan pengaruh panas.

Limbah serbuk kayu penggergajian adalah salah satu contoh limbah serat alami yang bersal dari serat tumbuh-tumbuhan yang tidak terpakai dan terbuang percuma. Biasanya, limbah serbuk kayu penggergajian ini dihasilkan dari hasil sampingan industri pengolahan kayu. Sifat- sifat dan kandungan yang terdapat dalam serbuk kayu penggergajian yaitu a) Serbuk kayu penggergajian mempunyai senyawa kimia berupa selulosa 50\% dan hemiselulosa (karbohidrat) dan lignin (non karbida) $10 \%-35 \%$ serta senyawa polimer minor. b) Bersifat higroskopis yaitu dapat menyerap atau melepaskan kadar air (kelembaban) sebagai akibat perubahan kelembaban dan suhu udara di sekelilingnya, 3) Mudah terbakar terutama dalam keadaan 
kering, 4) Sifat daya hantar terhadap panas sangat buruk, sedang daya hantar terhadap listrik tergantung kepada kadar air yang terkandung di dalam serbuk kayu tersebut, 5) Memiliki modulus elastisitas yang tinggi. Dengan modulus elastisitas yang tinggi inilah maka serbuk kayu sangat cocok digunakan sebagai bahan campuran untuk batu bata, sebab serbuk kayu ini dapat berguna sebagai penguat.

Dalam pembuatan batu bata diperlukan pengeringan yang diatur Temperatur Annealing-nya. Temperatur Annealing adalah temperatur pada proses pengeringan menggunakan alat. Alat ini berupa tungku kayu, tungku gas dan tungku listrik yang disebut juga dengan Electric Furnace. Temperatur Annealing berguna untuk pengeringan batu bata sehingga diperoleh batu bata yang baik dan sempurna.

Temperatur Anneling mempengaruhi sifat-sifat fisika batu bata seperti kuat tekan dan porositas. Pada proses Annealing atau dilakukannya variasi temperatur Annealing, partikel-partikel lempung akan beraglomerasi menjadi bahan padat kemudian permukaan butir yang berdekatan akan menyatu. Dalam keadaan ini terjadi penyusutan yang diiringi dengan pengurangan porositas. Reaksi ini lebih mudah terjadi pada temperatur Annealing yang tinggi, dimana atom-atom dapat dengan mudah bergerak dan menyatu. (Van Flack,1992).

Pada pembuatan batu bata limbah serat alami dilakukan variasi Temperatur Annealing. Dalam variasi Temperatur Annealing terdapat perubahan susunan partikel lempung dan serbuk kayu penggergajian. Perubahan inilah yang akan mempengaruhi sifat-sifat fisis dari batu bata limbah serat alami.

\section{METODE PENELITIAN}

Penelitian yang dilakukan adalah Penelitian Eksperimen Laboratorium. Dalam eksperimen dilakukan pembuatan batu bata, karakterisasi, pengambilan data kemudian analisis data, penarikan kesimpulan dan laporan hasil penelitian.

Variabel-variabel penelitian terdiri dari variabel bebas, variabel kontrol dan variabel terikat. Variabel bebas berupa temperatur Annealing. Variabel kontrol berupa proporsi lempung dan limbah serat alami yaitu 90\% $: 10 \%$, jenis limbah serat alami berupa serbuk kayu penggergajian, ukuran butir lempung dan limbah serbuk kayu penggergajian adalah 0,18 mm dan variabel terikat berupa kuat tekan dan porositas.

\section{Teknik Pengumpulan data dan analisa data}

Teknik Pengumpulan Data dalam penelitian ini dilakukan dengan dua cara yaitu pengumpulan data langsung dan data tidak langsung.

a.Pengumpulan data langsung

berupa proporsi lempung dan limbah serbuk kayu penggergajian, Temperatur Annealing, ukuran butir, beban tekan, luas bidang permukaan tekan, Delay Time, panjang sampel, kecepatan gelombang p di udara, dan kecepatan gelombang $\mathrm{p}$ pada sampel padatan.

b.Pengumpulan data tidak langsung berupa nilai kuat tekan dan porositas.

Nilai kuat tekan diperoleh dari perhitungan menggunakan persamaan berikut,

Kuat tekan $=\frac{P}{A}\left(\mathrm{~kg} / \mathrm{cm}^{2}\right)$ .......Persm (1)

Dengan; $P=$ beban tekan $(\mathrm{kg})$, dan $A=$ luas permukaan yang ditekan $\left(\mathrm{cm}^{2}\right)$.

Batu bata juga harus mempunyai nilai kuat tekan rata-rata dan koefisien variasi yang diijinkan, seperti dirincikan dalam Tabel 1. 
Tabel 1. Kuat tekan batu bata standar

\begin{tabular}{cccc}
\hline \multirow{2}{*}{ Kelas } & Kuat tekan rata-rata & Koefisien variasi yang diijinkan dari rata-rata kuat tekan bata yang diuji \\
\cline { 2 - 4 } & $\mathrm{Kg} / \mathrm{cm}^{2}$ & $\mathrm{~N} / \mathrm{mm}^{2}$ & $(\%)$ \\
\hline 25 & 25 & 2,5 & 25 \\
50 & 50 & 5 & 22 \\
100 & 100 & 10 & 22 \\
150 & 150 & 15 & 15 \\
200 & 200 & 20 & 15 \\
250 & 250 & 25 & 15 \\
\hline
\end{tabular}

(Sumber: SNI 15-2094-1991)

Nilai Porositas diperoleh dari suhu $105^{\circ} \mathrm{C}$, lalu dihaluskan dan diayak dengan perhitungan menggunakan Persamaan 2:

$$
\begin{gathered}
\phi=\frac{1 / v_{p}-1 / v_{m}}{1 / v_{f}-1 / v_{m}} \times 100 \% \ldots . . \text { Persm (2) } \\
\text { dengan } \phi=\text { porositas, } \mathrm{v}_{\mathrm{p}}=\text { kecepatan }
\end{gathered}
$$
gelombang $\mathrm{p}$ pada sampel yang diukur, $\mathrm{v}_{\mathrm{m}}=$ kecepatan gelombang $\mathrm{p}$ pada sampel padatan $(5480,6 \mathrm{~m} / \mathrm{s})$, dan $\mathrm{v}_{\mathrm{f}}=$ kecepatan gelombang $\mathrm{p}$ di udara $(340 \mathrm{~m} / \mathrm{s})$.

Data-data yang telah terkumpul ditampilkan dalam bentuk tabel dan grafik. Pengolahan data dilakukan dengan memakai persamaan yang telah ditentukan berdasarkan tinjauan pustaka.

\section{Bahan dan alat Penelitian}

Bahan penelitian terdiri dari Air, Lempung yang diambil pada daerah Payakumbuh-50 Kota, tepatnya di Situjuh Banda Dalam serta Bahan campuran berupa limbah serbuk kayu penggergajian diambil di tempat pembuangan limbah serbuk kayu.

Alat Penelitian terdiri dari Oven pengering, Alat penghalus, Ayakan ukuran 0,18 mm, Timbangan, Gelas ukur, Cetakan batu bata, Electric Funace dan Hydraulic Compressive Strength Machine serta Sonic viewer beserta perangkatnya.

\section{Prosedur Pembuatan batu bata limbah serat alami}

Prosedur Pembuatan batu bata limbah serat alami adalah (1) Lempung dan limbah serbuk kayu penggergajian masing-masing dikeringkan dengan menggunakan oven hingga ukuran butir 0,18 mm; (2) Lempung dan limbah serbuk kayu penggergajian dicampurkan dengan perbandingan komposisi 90\% : 10\%; (3) Campuran ini kemudian diberi air 5 liter sehingga menjadi plastis dan dapat dicetak; (4) Pencetakan menggunakan cetakan kayu berbentuk persegi dengan ukuran 6x6x6 $\mathrm{cm}$ dan cetakan dari paralon berbentuk silinder dengan diameter $7 \mathrm{~cm}$ dan tinggi $10 \mathrm{~cm}$; (5) Sampel batu bata limbah serat alami yang telah selesai dicetak kemudian dikeringkan di udara terbuka tetapi terhindar dari cahaya matahari langsung lebih kurang 2 minggu bertujuan untuk mengeluarkan air yang digunakan dalam proses pembuatan sampel dan sampel tidak retakretak; (6) Setelah itu dikeringkan lagi dengan Electric Furnace dengan variasi Temperatur Annealing yaitu : $700^{\circ} \mathrm{C}, 750^{\circ} \mathrm{C}, 800^{\circ} \mathrm{C}$ dan $850^{\circ} \mathrm{C}$; (7) Pada pembuatan batu bata limbah serat alami ini juga dibuat batu bata tanpa campuran limbah serat alami sebagai Standar pembanding. Batu bata tanpa campuran limbah serat alami ini hanya menggunakan bahan dasar berupa lempung dengan ukuran butir $0,18 \mathrm{~mm}$. Lempung ini diberi air $1200 \mathrm{ml}$ agar plastis dan dapat dicetak dengan ukuran cetakan 6x6x6 cm dan perlakuan pengeringan dilakukan sama seperti batu bata limbah serat alami dan (7) Batu bata yang telah dihasilkan dengan variasi temperatur Annealing ini kemudian dikarakterisasi berupa Uji kuat tekan menggunakan alat Hydraulic Compressive Strength Machine serta Uji porositas menggunakan alat Sonic viewer. 


\section{HASIL DAN PEMBAHASAN}

\section{Uji Kuat tekan}

Kuat tekan rata-rata dari batu bata limbah serat alami dengan variasi temperatur Annealing dan batu bata tanpa campuran limbah serat alami didapat dari data luas bidang tekan rata-rata, gaya tekan rata-rata, jumlah sampel tiap-tiap variasi Temperatur Annealing batu bata limbah serat alami dan batu bata tanpa campuran limbah alami terlihat pada Tabel 2.

Tabel 2. Data luas bidang tekan rata-rata, gaya tekan rata-rata, jumlah sampel tiap-tiap variasi Temperatur Annealing batu bata limbah serat alami dan batu bata tanpa campuran limbah alami.

\begin{tabular}{|c|c|c|c|c|c|}
\hline \multirow{2}{*}{ No } & \multicolumn{3}{|c|}{ Temperatur Annealing Jumlah sampel Luas bidang tekan rata-rata } & \multicolumn{2}{|c|}{ Gaya tekan Rata-rata } \\
\hline & ${ }^{0} \mathrm{C}$ & Buah & $\mathrm{cm}^{2}$ & $\mathrm{Kn}$ & $\mathrm{Kg}$ \\
\hline \multicolumn{6}{|c|}{ A. Batu bata limbah serat alami } \\
\hline 1 & 700 & 5 & 28,34 & $16,80 \pm 10,2$ & $1713,11 \pm 10,2$ \\
\hline 2 & 750 & 5 & 29,34 & $18,70 \pm 10,2$ & $1894,65 \pm 10,2$ \\
\hline 3 & 800 & 5 & 28,68 & $21,00 \pm 10,2$ & $2141,39 \pm 10,2$ \\
\hline 4 & 850 & 5 & 28,24 & $24,70 \pm 10,2$ & $2518,68 \pm 10,2$ \\
\hline \multicolumn{6}{|c|}{ B. Batu bata tanpa campuran limbah serat alami } \\
\hline 1 & 800 & 5 & 29,92 & $40,60 \pm 10,2$ & $4119,63 \pm 10,2$ \\
\hline
\end{tabular}

Dari data yang diperoleh pada Tabel 2 dapat ditentukan nilai kuat tekannya menggunakan Persamaan (1), sehingga didapat nilai kuat tekan rata-rata tiap variasi temperatur
Annealing batu bata limbah serat alami dan batu bata tanpa campuran limbah serat alami seperti terlihat pada Tabel 3.

Tabel 3. Nilai kuat tekan Rata-rata batu bata limbah serat alami dengan variasi Temperatur Annealing dan batu bata tanpa campuran limbah serat alami

\begin{tabular}{cc}
\hline TEMPERATUR ANNEALING $\left({ }^{\circ} \mathrm{C}\right)$ & KUAT TEKAN RATA- RATA $\left(\mathrm{kg} / \mathrm{cm}^{2}\right)$ \\
\hline A. Batu bata limbah serat alami & \\
\hline 700 & 60,44 \\
750 & 64,66 \\
800 & 74,65 \\
850 & 89,50 \\
\hline B. Batu bata tanpa campuran limbah serat alami & \\
\hline 800 & 137,93 \\
\hline
\end{tabular}

Dari Tabel 3A dibuat grafik hubungan antara kuat tekan rata-rata batu bata limbah serat alami dengan variasi Temperatur Annealing dapat dilihat pada Gambar 1. 


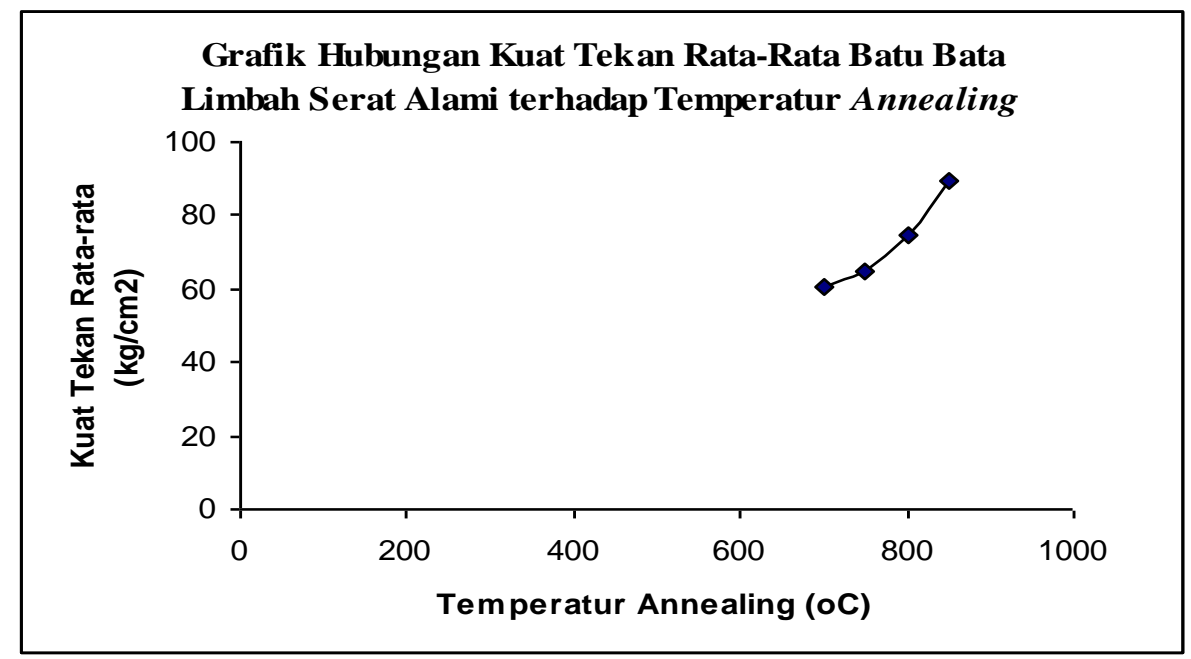

Gambar 1. Grafik hubungan kuat tekan rata-rata batubata limbah serat alami terhadap variasi temperatur Annealing.

Pada Gambar 1 terlihat bahwa temperatur Annealing sebanding dengan nilai kuat tekan dimana semakin tinggi temperatur Annealing, maka kuat tekan semakin tinggi pula. Pada Gambar 1 juga terlihat bahwa nilai kuat tekan tertinggi terdapat pada temperatur Annealing $850^{\circ} \mathrm{C}$. Dan dari hasil pengujian kuat tekan yang didapatkan, terlihat bahwa batu bata serat limbah alami dengan variasi temperatur Annealing sudah memenuhi syarat dari Standar Nasional Indonesia No.21/SII/78. Nilai rata-rata kuat tekan untuk temperatur Annealing $700^{\circ} \mathrm{C}$ adalah $60.44 \mathrm{~kg} / \mathrm{cm}^{2}$, temperatur Annealing $750^{\circ} \mathrm{C}$ adalah $64.66 \mathrm{~kg} / \mathrm{cm}^{2}$, temperatur Annealing $800^{\circ} \mathrm{C}$ adalah $74,65 \mathrm{~kg} / \mathrm{cm}^{2}$ dan temperatur Annealing $850^{\circ} \mathrm{C}$ adalah 89,5 $\mathrm{kg} / \mathrm{cm}^{2}$.

Dari hasil ini terlihat bahwa semakin tinggi temperatur Annealing, maka nilai kuat tekan batu bata limbah serat alami ini semakin tinggi. Hal ini disebabkan karena pada proses pembakaran dengan menggunakan variasi temperatur Annealing $850^{\circ} \mathrm{C}$ pembentukan batu bata limbah serat alami ini berlangsung lebih sempurna dibandingkan dengan variasi temperatur Annealing $800^{\circ}, 750^{\circ}$ dan $700^{\circ} \mathrm{C}$. Partikel- partikel lempung beraglomerasi sempurna menjadi bahan padat pada temperatur $850^{\circ} \mathrm{C}$. Hal ini disebabkan juga karena pada temperatur ini atom- atom lebih mudah bergerak dan menyatu. (Van Flack,1992)

Nilai kuat tekan untuk batubata limbah serat alami ini juga lebih baik dari pada kuat tekan batu bata hasil penelitian yang dilakukan Sri Handayani (2010) yang menyatakan bahwa penambahan serbuk gergaji sebanyak $10 \%$ pada batu bata menghasilkan kuat tekan rata-rata sebesar $25,72612 \mathrm{~kg} / \mathrm{cm}^{2}$.

Tetapi berdasarkan penelitian mengenai batu bata tanpa campuran limbah serat alami dengan ukuran butir $0,18 \mathrm{~mm}$, diberi perlakuan yang sama dengan batu bata limbah serat alami, maka batu bata tanpa campuran limbah serat alami dengan temperatur Annealing $800^{\circ} \mathrm{C}$ ini lebih tinggi nilai kuat tekan rata-ratanya yaitu sebesar $137,93 \mathrm{~kg} / \mathrm{cm}^{2}$ dibanding dengan nilai kuat tekan batu bata limbah serat alami dengan temperatur Annealing $800^{\circ} \mathrm{C}$ yaitu 74,65 $\mathrm{kg} / \mathrm{cm}^{2}$.

\section{Uji Porositas}

Nilai Porositas rata-rata dari batu bata limbah serat alami dengan variasi temperatur Annealing dan batu bata tanpa campuran limbah serat alami didapat dari Data jumlah sampel, panjang sampel, delay time dan kecepatan gelombang $\mathrm{p}$ terhadap variasi temperatur Annealing seperti Tabel 4. 
Chandra, A. N., Djamas, J., Ramli. 2016. Pengaruh Temperatur Annealing terhadap Sifat Fisis Batu Bata Limbah Serat Alami. Journal of Sainstek 8(2): 150-158

Tabel 4. Data jumlah sampel, panjang sampel, delay time dankecepatan gelombang $\mathrm{p}$ terhadap variasi temperatur Annealing

\begin{tabular}{cccccc}
\hline \multirow{2}{*}{ No } & Temperatur Annealing & Jumlah Sampel & Panjang Sampel & Delay time & $\mathrm{V}_{\mathrm{p}}$ \\
\cline { 2 - 6 } & ${ }^{0} \mathrm{C}$ & $\mathrm{Buah}$ & $\mathrm{m}$ & $\mathrm{s}$ & $\mathrm{m} / \mathrm{s}$ \\
\hline 1 & 700 & 1 & $9.2 \times 10^{-3}$ & $5.70 \times 10^{-3}$ & 16,14 \\
2 & 750 & 1 & $9.2 \times 10^{-3}$ & $5.70 \times 10^{-3}$ & 16,14 \\
3 & 800 & 1 & $9.2 \times 10^{-3}$ & $5,72 \times 10^{-3}$ & 16,09 \\
4 & 850 & 1 & $9.2 \times 10^{-3}$ & $5,36 \times 10^{-3}$ & 17,17 \\
\hline
\end{tabular}

Dari data yang telah diperoleh pada nilai porositas rata-rata tiap variasi Temperatur Tabel 4 dapat ditentukan porositas Annealing seperti pada Tabel 5. menggunakan Persamaan (2), sehingga didapat

Tabel 5. Nilai porositas rata-rata dan variasi temperatur Annealing

\begin{tabular}{cc}
\hline Temperatur Annealing $\left({ }^{\circ} \mathrm{C}\right)$ & Porositas \% \\
\hline 700 & 2,24 \\
750 & 2,24 \\
800 & 2,22 \\
850 & 2,10 \\
\hline
\end{tabular}

Dari Tabel 5 ini dibuat grafik hubungan Porositas rata-rata batubata limbah serat alami terhadap variasi Temperatur Annealing seperti Gambar 2.

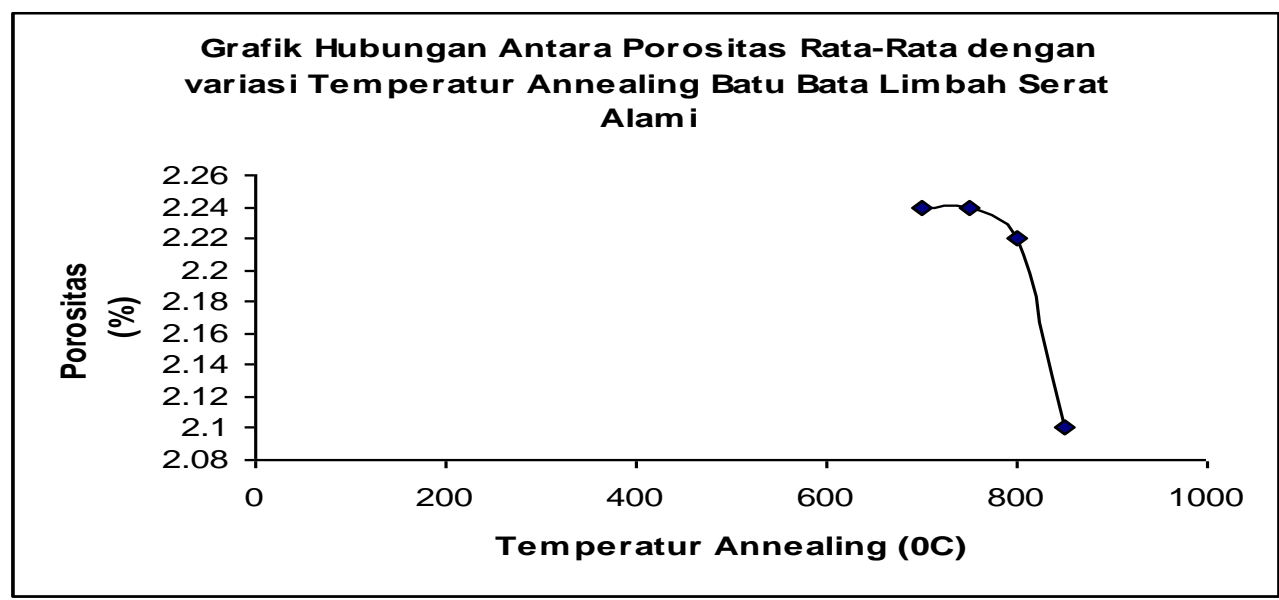

Gambar 12. Grafik hubungan porositas rata-rata dengan temperatur Annealing batu bata limbah serat alami

Pada Gambar 2 terlihat bahwa porositas terkecil adalah pada temperatur Annealing $850^{\circ} \mathrm{C}$, dan porositas terbesar adalah pada temperatur $700^{\circ} \mathrm{C}$ dan $750^{\circ} \mathrm{C}$. Dan berdasarkan 
hasil pengujian porositas batu bata limbah serat alami dengan variasi temperatur Annealing $700^{\circ} \mathrm{C}, 750^{\circ} \mathrm{C}, 800^{\circ} \mathrm{C}$ dan $850^{\circ} \mathrm{C}$ diperoleh nilai porositas masing-masing $2,24 \%, 2,24 \%, 2,22 \%$ dan $2,10 \%$. Terlihat bahwa semakin tinggi temperatur Annealing, maka semakin kecil persen porositasnya. Nilai porositas ini didapat demikian karena dengan temperatur Annealing yang tinggi, maka proses aglomerasi menjadi bahan padat dan membuat permukaan butir menjadi lebih berdekatan dan menyatu. Penyatuan inilah yang membuat semakin berkurangnya pori- pori atau porositas. (Van Flack,1992)

Dari keadaan diatas dapat juga terlihat hubungan antara kuat tekan dengan porositas. Dimana dengan temperatur Annealing yang tinggi didapatkan porositas yang rendah dan dengan porositas yang rendah inilah dihasilkan kuat tekan yang tinggi.

\section{KESIMPULAN}

Mengacu pada pencapaian tujuan penelitian ini, maka dapat disimpulkan sebagai berikut:

1. Kuat tekan maksimal batu bata limbah serat alami diperoleh pada temperatur Annealing $850^{\circ} \mathrm{C}$ yakni $89,5 \mathrm{~kg} / \mathrm{cm}^{2}$ dan memenuhi SNI 15-2094-1991 (DSN, 1991).

2. Porositas minimum batu bata limbah serat alami diperoleh pada temperatur Anneling $850^{\circ}$ yakni $2,10 \%$.

\section{SARAN}

Berdasarkan kesimpulan di atas, maka dikemukakan saran sebagai berikut:

1. Dalam pencetakan sampel usahakan sampel benar-benar rata permukaannya, sehingga tepat dalam penentuan karakterisasi.

2. Dalam pengeringan sampel batu bata limbah serat alami menggunakan Electric Furnace usahakan benar-benar kering air, sehingga didapat hasil yang lebih maksimal.

\section{DAFTAR KEPUSTAKAAN}

Amir AH. 2002. Pemanfaatan Limbah untuk Bahan Bangunan. Bandung: Modul Puslitbang Pemukiman.

Anshar M, Anwar M dan M Idris. 2001. Perilaku Suhu dan Waktu Pembakaran Terhadap Ciri Batu Bata Merah, http://www.dikti.org/p3m/3.html.

Basri LH. 1986. Pemanfaatan Sekam Untuk Bahan Bangunan, Kertas Kerja Perorangan, Deperin Sumbar.

Bowles. Joseph E. 1991. Sifat-Sifat Fisis Dan Geoteknis Tanah (Mekanika Tanah). Jakarta: Erlangga.

Dewan Standardisasi Nasional. 1991. SNI 152094-1991. Mutu dan Cara Uji Bata Merah Pejal, Jakarta.

Dieter GE. 1996. Metalurgi Mekanik, edisi ketiga, terjemahan Sriati Djaprie. Jakarta: Erlangga.

Handayani S. 2010. Kualitas Batu Bata Merah dengan Tambahan Serbuk Gergaji. Jurnal Teknik Sipil dan Perencanaan. Nomor 1 Volume 12-Januari 2010, Hal:41-50.

Hartomo. Anton J. 1994. Mengenal Keramik Canggih. Yokyakarta: Andi Offset.

Harsono, Heru. 2002. Pembuatan Silikon Amorf dari Limbah Sekam Padi, Jurnal ILMU DASAR, Vol.3,No.2,2002 hal 98103.

Indra, Ade. 2013. Pengaruh temperatur Pembakaran Pada Komposit Lempung/Silika RHA terhadap Sifat Fisis (Aplikasi pada Bata Merah), Jurnal Teknik Mesin Volume 3 Nomor 2 Oktober 2013, Hal:60-65.

Kemino. 1995. Penelitian Pemanfaatan Limbah Industri Pengolahan Kayu Sebagai Bahan Baku Pembuatan Bata Cetak. Jurnal Penelitian Permukiman, Vol.11-7/1995.

Manggasa A, dkk. 1996. Pengembangan Teknologi Pengolahan Serbuk Gergaji Sebagai Bahan Pengisi Pada Pembuatan Bata Cetak, Laporan Proyek, Balai Industri Ujung Pandang. 
Chandra, A. N., Djamas, J., Ramli. 2016. Pengaruh Temperatur Annealing terhadap Sifat Fisis Batu Bata Limbah Serat Alami. Journal of Sainstek 8(2): 150-158

Munandar M. 2001. Ketentuan Dinding Tembok Wilayah Gempa, Buletin Pengawasan No.30\&31 Th 2001.

Nada I made. 2013. Karakteristik Fisik Campuran Batu Bata dengan Memanfaatkan Abu Sisa Pembakaran Limbah Kayu, Kurva Teknik Vol 2, No 1 (2013): Jurnal Kurva Teknik Volume 2 Nomor 1 Tahun 2013, Hal: 88-97.

Rahmawati, Anis, dkk. 2015. Penambahan Abu Jerami dan Abu Sekam pada Campuran Batu Bata untuk Meningkatkan Kualitas dan Efisiensi Produksi Batu Bata Industri Tradisional, Jurnal Eco Rekayasa Volume 11 Nomor 1, Maret 2015, Hal:16-22.
SII/DP/BPPI/BBK/73/78 Mutu Dan Cara Uji Lempung. Bandung.

SII No 0021-78 Mutu Dan Cara Uji Batu Bata Merah Pejal. Padang.

Suryaningsih. 2005. Karakterisasi Fisis Lempung yang Terdapat di Daerah Payakumbuh dan Padang Sibusuk Untuk Body Keramik, Skripsi. Universitas Negeri Padang.

Sutopo.1987. Ilmu Bangunan. Jakarta: Bumi Aksara.

Van.Valack Lawrence. 1992. Ilmu dan Teknologi Bahan. Jakarta: Erlangga. 